\title{
Syncretistic Vernacular Architecture Santa Fe, New Mexico
}

Benjamin King Shacklette, AIA
Texas Tech University, Lubbock, Texas

\begin{abstract}
:
The subject of this paper is the Westside/Guadalupe Historic District, established in 1983. The Westside originates from seventeenth century pre-industrial building methods and land use patterns associated with agricultural based societies that in many instances were extended family settlements. A predominant characteristic is growth by accretion and modification that often produces an eccentric ad hoc result that can be described as vernacular or folkloric. This has been popularly called Santa Fe Vernacular Style. This paper demonstrates a localized community process of building and place making resulting from the syncretism of various regional and national influences spanning three distinctive eras of development: Spanish Colonial/Mexican Independence (1600-1846), U. S. Territorial (1846-1912), and Statehood (1912-present). Representative examples of Westside buildings are evaluated showing predominant patterns of settlement, spatial configurations, material usage, and architectural detailing delineating a contemporary building tradition based on an accurate understanding of history and local identity.
\end{abstract}

This paper claims that the Westside community is a relevant example of an authentic self-generating community building process that can continue to thrive through a collaboration of stakeholders; community, client, designer, and contractor. This collaboration will require each stakeholder to have a highly developed understanding of local history and the conditions facing modern civilization. This knowledge can inform new construction and the renovation of existing structures with the aim of creating unique and particular environments that value innovation over imitation

In the human endeavor to claim and sustain culturally relevant forms and spaces for living, architecture plays a dual role in defining and dissolving the physical and psychological borders between cultural groups occupying common domains. Santa Fe, New Mexico is a study of the transition from ancient market place to global market economy balancing the need to sustain authentic community life with the necessity to maintain a tourism industry marketable to consumers who are visitors or newcomers. Northern New Mexico is home to some of the oldest preindustrial folkloric vernacular ${ }^{1}$ architecture in the United States. A significant portion of the "historic" downtown structures frequented by tourists and "upscale" shoppers were built and rebuilt, from the early 1900's onward, in a modern vernacular ${ }^{2}$ remaking of an imagined world rooted in historical fact and fantasy.

This has created a local attitude about architecture framing an original approach to a culture tourism industry; a form of commerce capable of generating substantial economic benefits in many ways and at various levels. Santa Fe is distinctive, and thus vernacular ${ }^{3}$ in the fact that language, food, art, dress, and building traditions are uniquely Santa Fe and particular to the immediate regions surrounding the city. Paul Oliver defines vernacular architecture as "The dwellings and places of the people", these dwellings relate to specific environmental contexts and available resources, and they are customarily owner-or community-built utilizing traditional technologies. "He asserts that all forms of vernacular architecture are designed to address specific needs, and express the values, economies, and "ways of living of the cultures that produce them". ${ }^{4}$

The Westside/Guadalupe Historic District was established in 1983 and is the most recent of five historic districts in Santa Fe. It is the combination of two neighborhoods that have slowly grown together defining a distinct architectural terrain within Santa Fe. The term "Westside" refers to the western extension of San Francisco Street north of the Santa Fe River, and a small rural settlement to the south named the Barrio de Guadalupe. The majority of structures are consistent with the New Mexican owner-as-builder tradition that originates from pre-industrial building methods and land 
use patterns associated with village making and agricultural based settlements that in many instances are extended family settlements.

A particular attribute of primitive mud or adobe construction is its instability as a long term building material. Real sun dried adobe brick with mud plaster has a tendency to melt and erode. Early foundation systems were prone to shift, and heavy timber ceiling beams covered with a thick layer of dried mud tended to force walls to thrust outward. Exterior load bearing adobe walls were constantly being strengthened and rebuilt. The canted or battered look of these walls is often due to periodic stabilization. A simple method to counteract lateral forces from the roof was to shore up the exterior walls with additional buttressing. Real adobe can last for centuries with constant care. Because of this periodic maintenance and reconstruction adobe buildings in New Mexico have a plastic quality in that they change and grow over time allowing builders the opportunity to introduce elements from different architectural styles and eras. The syncretistic process is often ongoing and not limited to a onetime occurrence.

One of the best-known examples of this is the Palace of the Governors located on the Santa Fe Plaza. Built by the Spanish in the early 1600's it has seen numerous reconstructions over the centuries. No one knows exactly what it looked like during the Spanish Colonial period, but early photographs indicate that by 1868 a wood colonnade in the Greek revival style had been added and by 1881 the main façade had been rebuilt in the Queen Anne style popular in the territorial era. In 1909 the palace became the property of the Museum of New Mexico, and by 1913 the original structure was rebuilt again to resemble the Spanish Colonial style based on a mix of fact and conjecture. In each of the earlier renovations the intent was to remake the Palace into a contemporary building in tune with the prevailing currents of architectural style. The 1913 renovation signifies the beginning of the modern Santa Fe Revival movement that rejected contemporary mainstream influences and looked to the past for inspiration. Like the Santa Fe Plaza, the development of the Westside and Guadalupe neighborhoods parallel the three stages of cultural development in Northern New Mexico.

\section{SPANISH COLONIAL/MEXICAN INDEPENDENCE: I610-1846}

Spanish colonists from Mexico City founded Santa Fe in 1610. The Spanish combined regional Pueblo mud building traditions with Spanish-Moorish adobe brick construction techniques creating the distinctive elements of Santa Fe style architecture that exist to the present day such as the portal or covered walk way, hewn wood beams called vigas, and timber supported lintels for narrow doors and windows.

Early Santa Fe was a blend of colonial Mexican cities and Pre-Columbian villages creating the factual basis for the modern day Spanish/Pueblo or Spanish/Indian style of architecture that is preeminent in Santa Fe today. The Spanish Colonial period officially ended in 1822 when Mexico won independence from Spain, but architecture remained virtually unchanged throughout the Mexican Independence period. The typical building of this era was a linear progression of single rooms that formed either straight line, L shaped, or U shaped configurations. ${ }^{5}$ (See Figure 1)
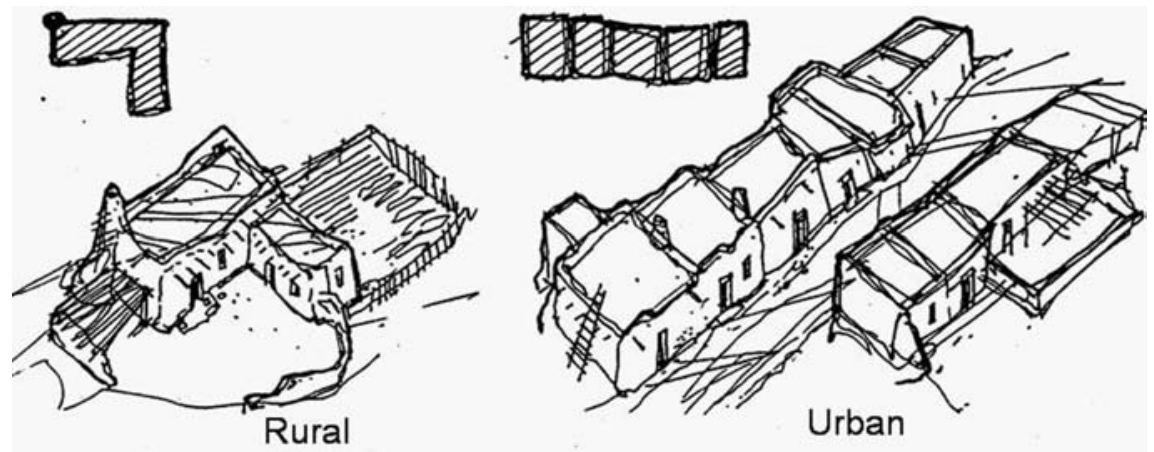

Figure 1. Mexican Colonial Period building configurations 


\section{AMERICANTERRITORIAL: |846-1912}

In 1846 the United States went to war with Mexico and Brigadier General Stephen Kearny occupied Santa Fe. In 1848 U.S. troops captured Mexico City and Nuevo Mexico became the territorial property of the U.S. under the Treaty of Guadalupe Hidalgo. Like the Spanish before them the Americans, out of necessity, "forced a merging of Pueblo Spanish style elements with the Greek Revival taste of these Anglo newcomers" 6

In the late 1800's Victorian architectural influences were also blended with Pueblo building elements. (See figures 2 and 3) The Americans integrated adobe for walls with milled woodwork for columns and openings, fired brick coping, and pitched roofs creating the Territorial or Anglo/Pueblo style. A widely held view during the Territorial Period regarded mud architecture as a hindrance to statehood not being "American" in origin and further promoting the "backwardness" of New Mexico. Non-English speaking Catholics were not regarded as prospective loyal citizens and adobe buildings accentuated their presence. In the more developed areas of Santa Fe, the trend became contemporary American architecture ranging from Romanesque to Italianate styles attempting to look typically American while downplaying a Spanish/Mexican past. "Between cultures of such opposite temperament, conflict was inevitable" ${ }^{7}$ Only in the poorer sections of town were the traditional communal adobe building techniques continued as a matter of survival and dire necessity. In the contest for ideological terrain, architecture played a preeminent role in the early history of Santa Fe. As the 20th century began it looked as though adobe architecture would fade into history as Santa Fe, Albuquerque, and Las Vegas, New Mexico increasingly adopted the look of any typical American city.

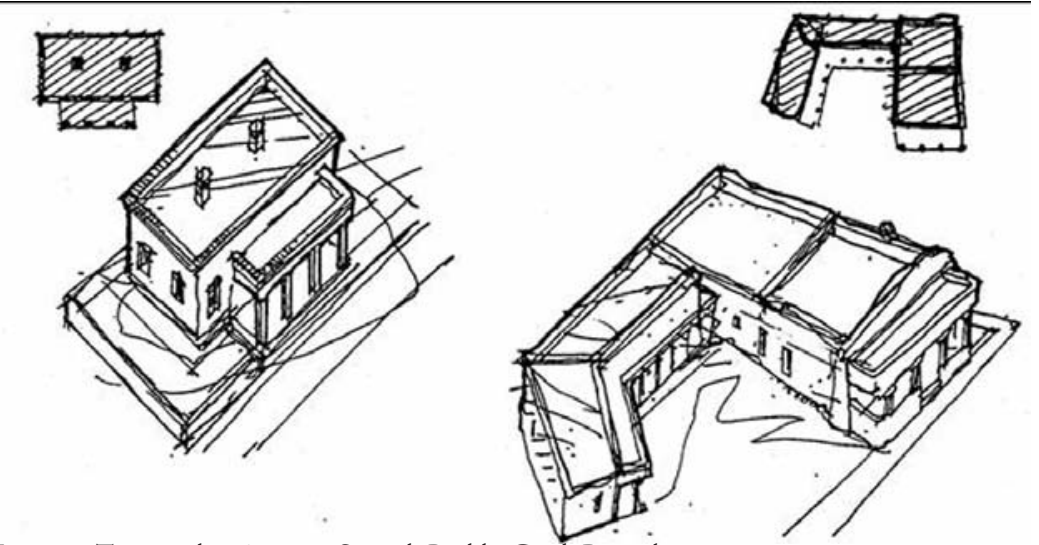

Figure 2. Territorial 1850-1870 Spanish Pueblo-Greek Revival
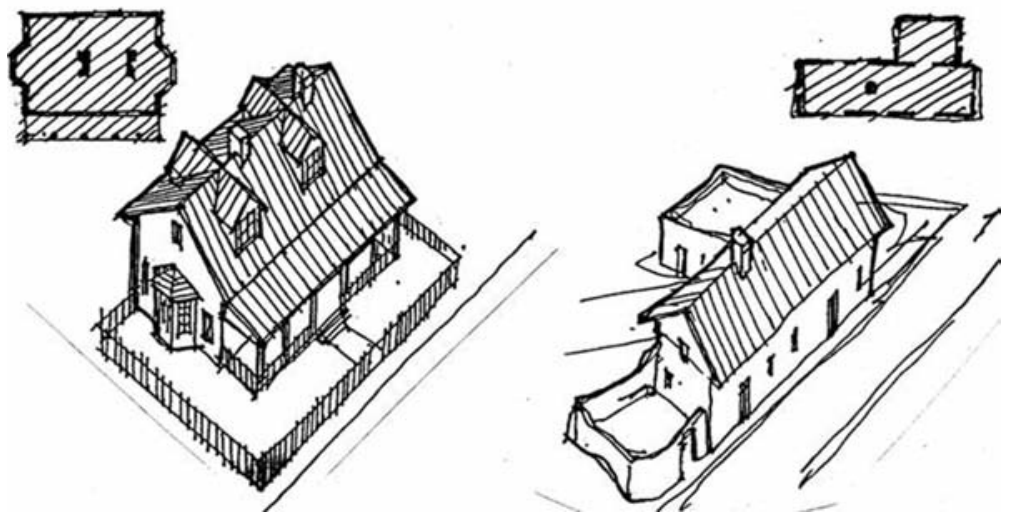

Figure 3.Territorial 1870-1900 Spanish Pueblo-Victorian 


\section{NEW MEXICO STATEHOOD: I9I2-PRESENT}

Following statehood, a dramatic shift in attitudes began to take place in Santa Fe. The new tourism industry, created by the development of trans-continental railroad transportation, capitalized on the growing interest in Southwest Indian cultures now accessible to travelers passing through Santa Fe. Archaeologists pioneered preservation techniques in discovering the ancient places of cultures long vanished at Chaco and Bandalier. Surviving tribal centers at Acoma and Taos intrigued scholar and tourist alike spurring an interest in preserving Native American history through regional tourism. New Pueblo and Territorial style building were constructed throughout downtown Santa Fe that were conceptually based on authentic adobe buildings from antiquity, but were actually built of brick and clay tile plastered with cement-based stuccos resembling adobe construction. At the same time, a controversial approach to archaeology was born: ruins were excavated and stabilized and then new construction was added enabling the casual tourists to experience the building as it had been, or in some cases as it might have been. Motivated by a concern that Santa Fe was becoming too much like any typical American city, and the potential economic benefits of being different, many existing buildings throughout New Mexico underwent façade reconstruction to become more "historically authentic" even though the effort was not aimed at accurate preservation but mythical representation. This process of "adobification," is a particular Santa Fe phenomenon. More than an architectural "facelift", this practice can be understood as a form of cultural denial by deliberately removing the real history of social contest and political conflict and replacing it with a mythical sense of place.

The emphasis instead on a romantic story deprives people of an image of themselves as active agents for contemporary social change. Such fictionalized reality also inhibits the hybridization of the traditional with the modern, the local with the international, which is necessary for the continued vitality and relevance of any local culture. ${ }^{8}$

It can be argued that the territorial era addition of Victorian elements to the Palace of the Governors was stylistically incorrect and yet these earlier renovations demonstrate the ability of a regional architectural method to remain viable by bridging regional history with current trends and attitudes.

The Spanish/Pueblo revival movement, ushered in by early 20th century idealists (a loose confederation of architects, artists, archeologists, and civic boosters) effectively ended the original Santa Fe process of inventive adaptation, replacing it with a fixed and rigidly defined style that resisted innovation and experimentation. "The philosophy of the Arts and Crafts Movement provided a framework for combining a clarified nationalism, a concern for social reforms, economic revival and vernacular art." The 1957 Santa Fe Historical District Ordinance, one of the first in the U.S., mandated that all new construction and renovation in historic districts conform to stylistic guidelines that recognized two categories of architectural style. Old Santa Fe Style, or building designs that strictly adhere to Spanish/ Pueblo Revival or Territorial Revival architectural rules, and Recent Santa Fe Style defined by a set of criteria that includes colors, details, and massing that achieve compatibility with historic revival buildings. The modern visual continuity of Santa Fe relies heavily on the effort to maintain unity through stylistic homogeneity or compatibility. This is informed by the traditional folk vernacular of the preindustrial age resulting from ethnicity, geography, site and landscape, and building materials and techniques unique to the area and to the time period. ${ }^{10}$

\section{THE WESTSIDE/GUADALUPE HISTORIC DISTRICT TODAY}

Since the 1950's, the Westside Neighborhood has gradually become part of modern-historic Santa $\mathrm{Fe}$, physically and psychologically, although long time residents still refer to this community as "the village" because of its unified small town scale and the interconnected character of its buildings. Today, the natural borders of the Westside are giving way to the prevalent trend of historic iconography most often associated with popular Pueblo Revival style that for a century has proliferated throughout mainstream Santa Fe particularly around the Plaza and in the more affluent neighborhoods. Until the 1980's, the Westside neighborhood was traditionally considered separate from the ideal rebuilding of Santa Fe before the age of tourism and gentrification. 
During the 1920s the neighborhood population doubled, and then more than doubled again by the end of World War II. Of the 686 buildings surveyed in the Westside/Guadalupe Historic District in 1985, 71\% were built before 1946. The relatively flat level strips of irrigated land were easily divided into building lots, with narrow lanes the along property lines giving access to the houses. This growth occurred not as major subdivisions but as piecemeal divisions of individual agricultural parcels into small building lots. ${ }^{11}$

The Westside neighborhood thrived being physically close to Santa Fe and borrowing freely from the various contemporary architectural influences of the day. It survived being psychologically distant from the popular image of modern Santa Fe being a working class neighborhood separated from downtown and the plaza by the rail yard. Because of this separateness much of the Westside neighborhood escaped the 20th century revival movement that first swept downtown Santa Fe after 1912. The term Santa Fe Vernacular Style is often used in Santa Fe today to identify structures that are non-professionally built, constructed primarily of regional materials, and to denote buildings that express a fusion, or syncretism of Hispanic and Anglo cultural ideologies through a localized convention of building borrowing freely from a wide range of influences particular to, or in some cases common to each group. Figure 4 shows the number and location of buildings in the Santa $\mathrm{Fe}$ Vernacular Style. Santa Fe or Hispanic Vernacular architecture differs from professional built "Pueblo Revival Style" architecture in the inventive process of building and the personalized aesthetic intent expressed by the owner/designer/builder.

A predominant characteristic is growth by accretion or periodic expansion and adaptation.(See figure 5) It is a regional method of building that is particular to the Westside. Van Dorn Hooker, past University Architect at the University of New Mexico, offers a definition of vernacular architecture that addresses the relationship between culture and means of production.

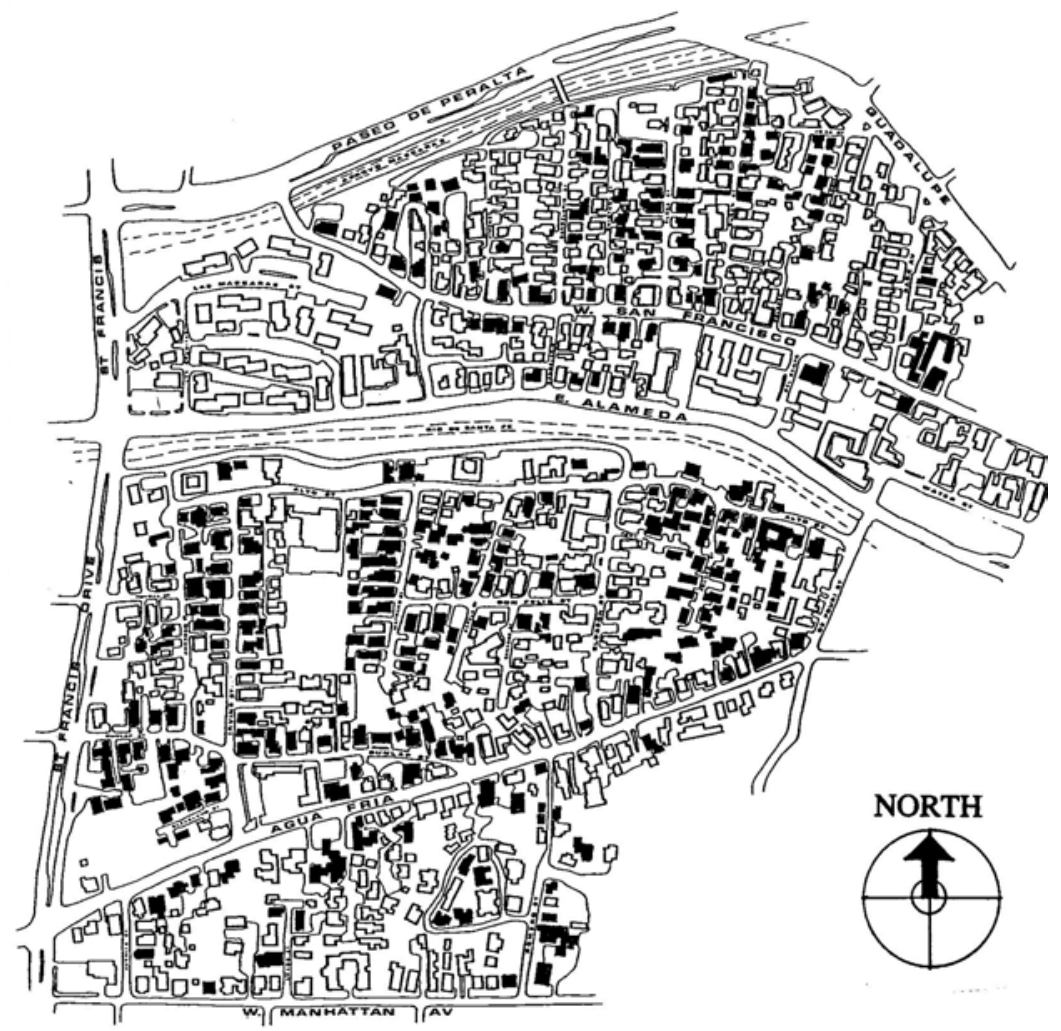

Figure 4 Map of the Westside/Guadalupe Historic District showing number and location of Vernacular buildings (darkened). 
The term 'vernacular' is borrowed from language, where it means 'the language or dialect... naturally spoken by the people of a particular country or district.' The phrase 'vernacular architecture' was first used in England in the 1850's to describe medieval houses which had no other place in the artistic and stylistic categories set down by 19 th century academics. More recently it has come to mean any structure devoted to everyday uses built by unschooled, but not unskilled, craftsmen working within a commonly understood cultural and technical tradition. $^{12}$

The distinctive architectural character of the Westside/Guadalupe Historic District results from a syncretism ${ }^{13}$ of regional Hispanic building methods and 19th and 20th century Anglo/American architectural trends. It is a cross-section of the various layers of social and cultural influences that have shaped Santa Fe and the American Southwest. The evolution of house types from 1850 to 1950 (see figure 6) shows that as emergent Anglo-American architectural trends filtered into the Westside, the mostly adobe constructed structures adopted various patterns regarding roof, porch, and doors and windows.

Prior to the arrival of the Americans, Hispanic traditions in building favored the enclosed courtyard scheme (See figure 7.) that usually started as an "L" shaped configuration that in time would grow to enclose a private and protected interior space. This type of building was more common in the outlying areas of town associated with agriculture. In the more dense areas of the interior city, artisans and merchants preferred the linear organization of single file rooms along the street edge (See figure 8) Doors opened directly onto the street and formed a hard edge. As Anglo and Hispanic cultures began to merge in the 19th century, density increased forming ad-hoc cluster settlements that were often positioned near water and organized around the acequias or irrigation ditches that ran from the Santa Fe River into the fields. (See figure 9.)

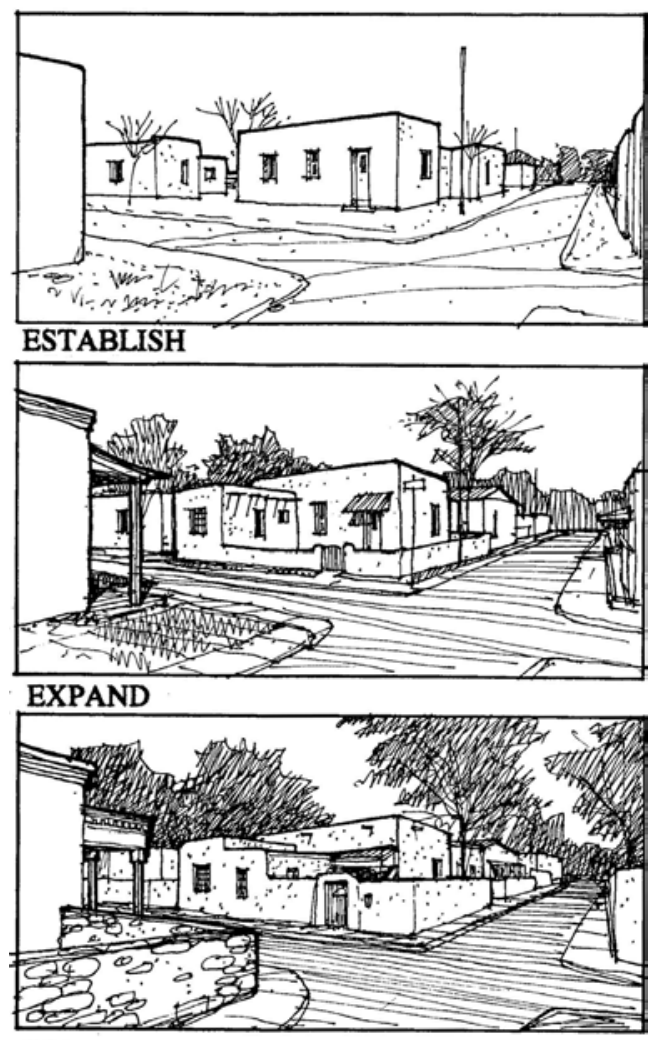

COMPLETE

Figure 5 Three stages of incremental growth 


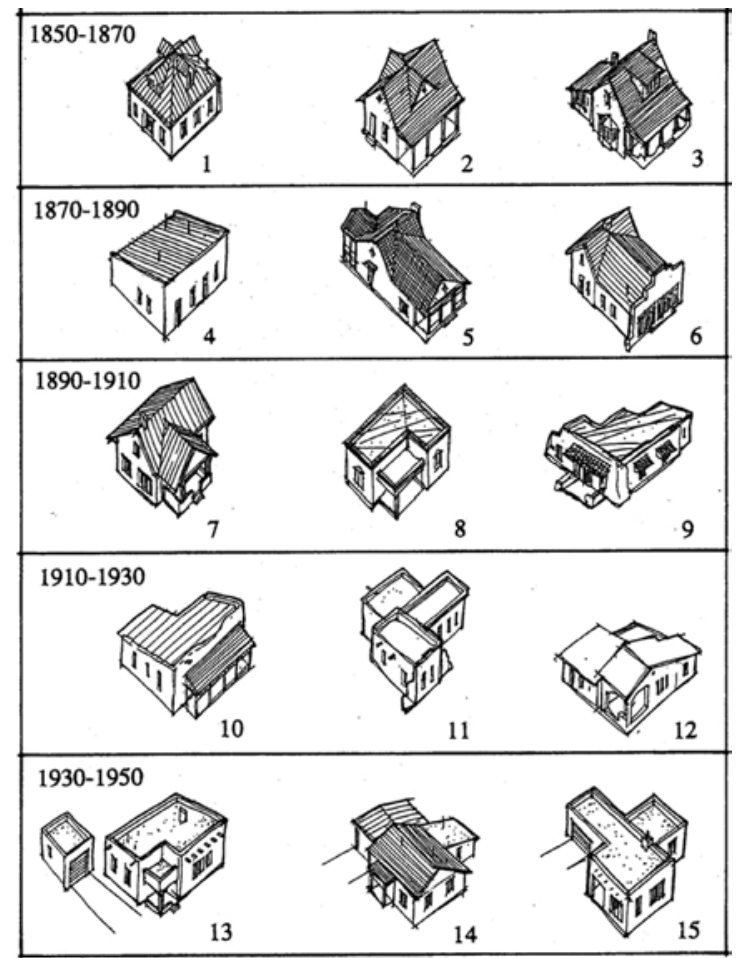

Figure 6 Syncretistic Evolutions of House Types. Westside/Guadalupe Historic District 1850-1950

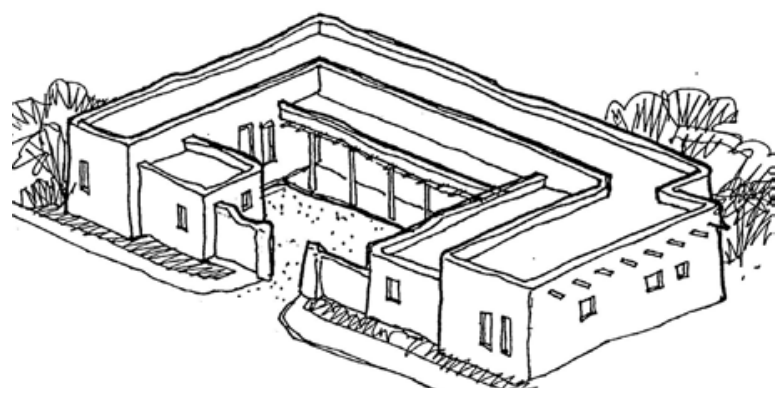

Figure 7 Enclosed courtyard house.

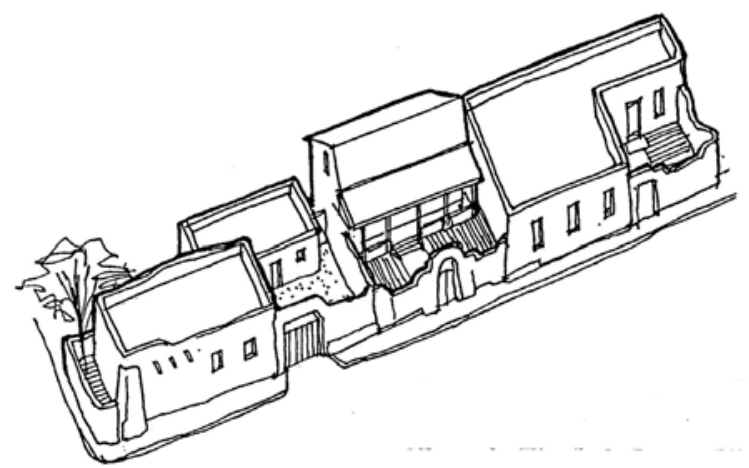

Figure 8 Linear street edge formed by attached houses and walls. 


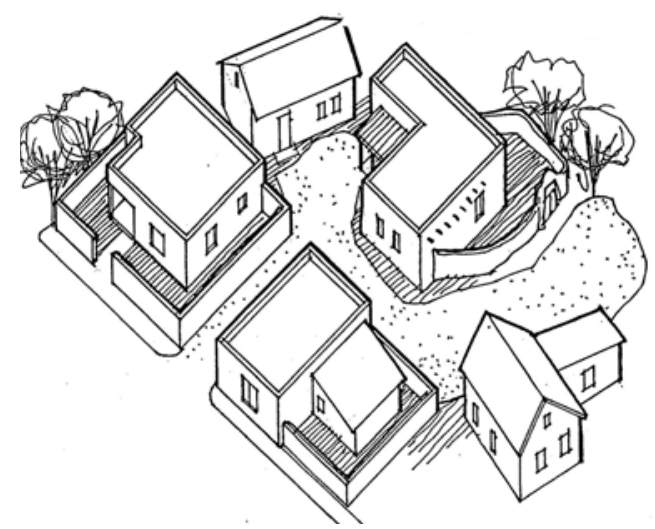

Figure 9 Multiple house units in informal clusters.

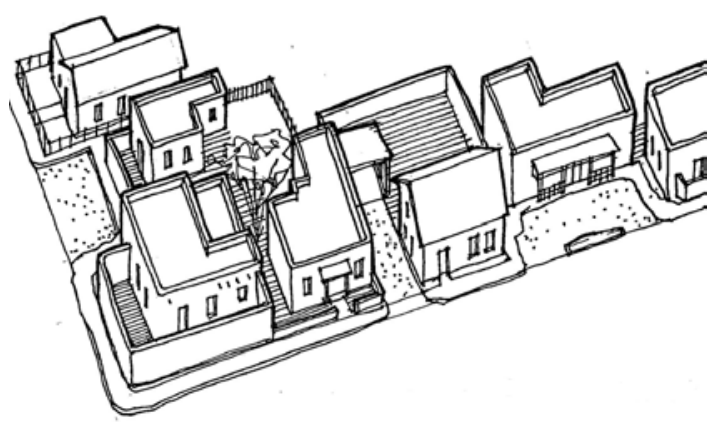

Figure 10 Mixed housing types with various yard configurations.

In time the Anglo American preference for a front yard necessitated the placement of the building back from the curb creating an undulating effect along the street edge. (See figure 10) Some residents preferred low picket fences and open front yards where vehicles could be parked while others constructed high privacy walls.

This random relationship of house to street edge combined with a highly unstructured approach to creating private drives and alleys has over time defined the vernacular and organic character of this neighborhood.

The Larragoite Residence at 803 Agua Fria Street (See figure 11.) was first documented on a warranty deed dated 1866 in the name of Armando Larragoite. This building has served as a residence, a grocery store, a liquor store, and a meat market before being restored to a private residence for Larragoite's descendants, who still live there today. The gables are covered with wood shingles and the roof is sheathed in tern plate metal, a roofing material introduced to Santa Fe in the 19th century. Considered an excellent example of Santa Fe Vernacular style the structure shows incremental additions and modifications that reflect various architectural influences. The original wall construction is load-bearing adobe that once supported flat mud roofs. Many Hispanic and Anglo homeowners constructed pitched roofs over the original structures as a modern improvement over the leaky mud roof.

This also created additional space for storage, and in some cases for living. One chimney is brick and the other is stone indicating different times of construction. The porches rest on stone and wood columns reminiscent of the Arts and Crafts style.

The residence at 707 Agua Fria originated as an adobe flat roofed farmhouse dating back to the 1800s (see figure 11). The original adobe box has been flanked by newer additions including shallow 


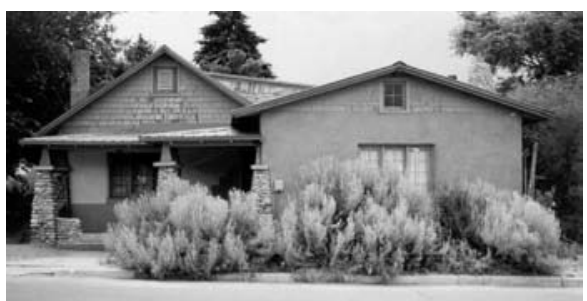

Figure 11 Larragoite R esidence at 803 Agua Fria Street

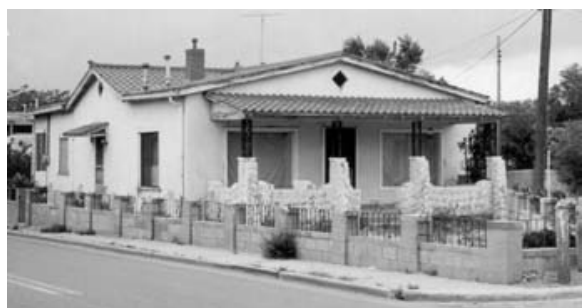

Figure 12 Residence at 707 Agua Fria Street

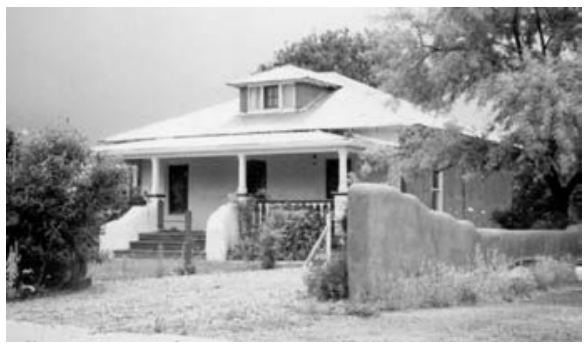

Figure 13 Residence at 130 Romero Street

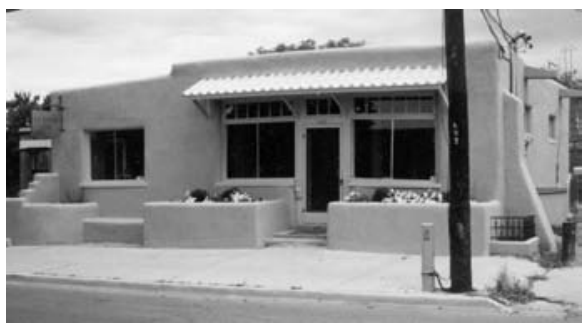

Figure 14455 W. San Francisco Street

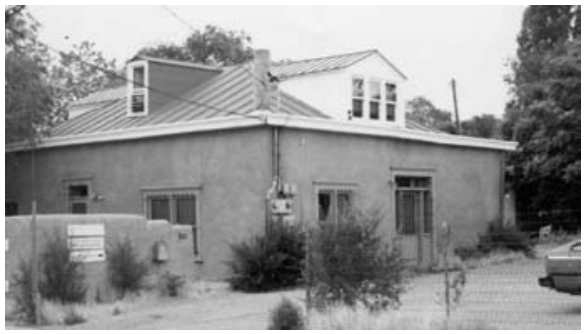

Figure 15511 W. San Francisco Street 
pitched roofs covered with pressed tin to look like Spanish tile reminiscent of the California Mission Style. The rock pedestals and triangular attic windows are evidence of the Arts and Crafts bungalow influence.

The residence at 130 Romero Street is a square "salt box" plan with a projecting hipped ridge dormer again reminiscent of the Craftsman influence (see figure 13). The front porch is carried on Greek revival style columns supported by adobe pedestals connected by Victorian style lathed balustrades. The tall windows under the porch recall the Queen Anne period.

The small business located at 455 W. San Francisco Street demonstrates the blending of Pueblo and Art Deco massing popular in the 1920's and 1930s (see figure14). California Mission Style canopies of metal "tile" roofing on cast iron frames supported by brackets cover wide large windows made possible by the introduction of clay tile wall construction. Buttressing at the corner is decorative and not structural indicating an attempt to incorporate Pueblo Revival aesthetic.

Dating from the late 1800s the two-story structure at 511 W. San Francisco Street (see Figure 15) is illustrative of the syncretism of Hispanic adobe architecture and Anglo territorial influences. The doors feature transoms and sidelights typical of the Queen Ann style. The high-pitched roof is standing seam metal accommodating cross-gabled ridge dormer windows. This mixing of Hispanic and Victorian elements is typical of the period from 1880 to 1920 when builders throughout remote villages and rural communities of northern New Mexico merged local traditions with national architectural themes and configurations.

\begin{abstract}
The concept of a local or national culture is a paradoxical proposition not only because of the present obvious antithesis between rooted culture and universal civilization but also because all cultures, both ancient and modern, seem to have depended for their intrinsic development on a certain cross-fertilization with other cultures. ${ }^{14}$
\end{abstract}

One of the most recognizable elements of Westside vernacular architecture is the walled entrance. Owing its origins to the Spanish zagaun entrance of the traditional enclosed hacienda plan, this element is often the most elaborate expression of the occupant and in some instances is the handiwork of the building owner, or a local artisan. Westside residents employ a wide range of technical and artistic approaches to the entrance in the design of the door and the framing of the entrance with arch or lintel. (See figure 16)

\title{
THEWESTSIDE/GUADALUPE HISTORIC DISTRICT TOMORROW
}

In some cases, the descendants of the original owners and/or builders still reside in the Westside/ Guadalupe Historic District. Others have moved on, choosing to take advantage of escalating real estate prices by selling to new owners from outside the local ethnic and cultural community. The Westside is no longer an "affordable" Santa Fe neighborhood as it once was. Modern real estate practices emphasize the principles of industrial standardization and rely less on the uniqueness of vernacular craft. Speculators and developers buy out Westside residents and "rebuild" the old structures to resemble fashionable Modernistic Santa Fe Style architecture. (See figure 17).

\begin{abstract}
Modernism did its immense damage in these ways: by divorcing the practice of building from history and the traditional meanings of building: by promoting a species of urbanism that destroyed the age-old social arrangements and, with, the urban life as a general proposition; and by creating a physical setting for man that failed to respect the limits of scale, growth, and the consumption of natural resources ${ }^{15}$.
\end{abstract}

James Kunstler's observation on the negative impacts modernism had on the making of livable and meaningful communities suggests the need to study the contemporary possibilities that spring from syncretistic vernacularism. The original intent of the Santa Fe Pueblo Revival was to resist the effects of mainstream American culture while all along relying on that very same culture to find Santa Fe distinctive and different. The Westside helps to define Santa Fe not so much as a city different from other places, but a city differentiated against itself tempted to erase the evidence of a turbulent, multicultural, self-expressive, and less romantic reality. A completely harmonious architectural landscape is not necessarily evidence of an authentic community process. The Westside resulted from nearly two centuries of conflict arising from the clash of Hispanic and Anglo-American cultures and the 

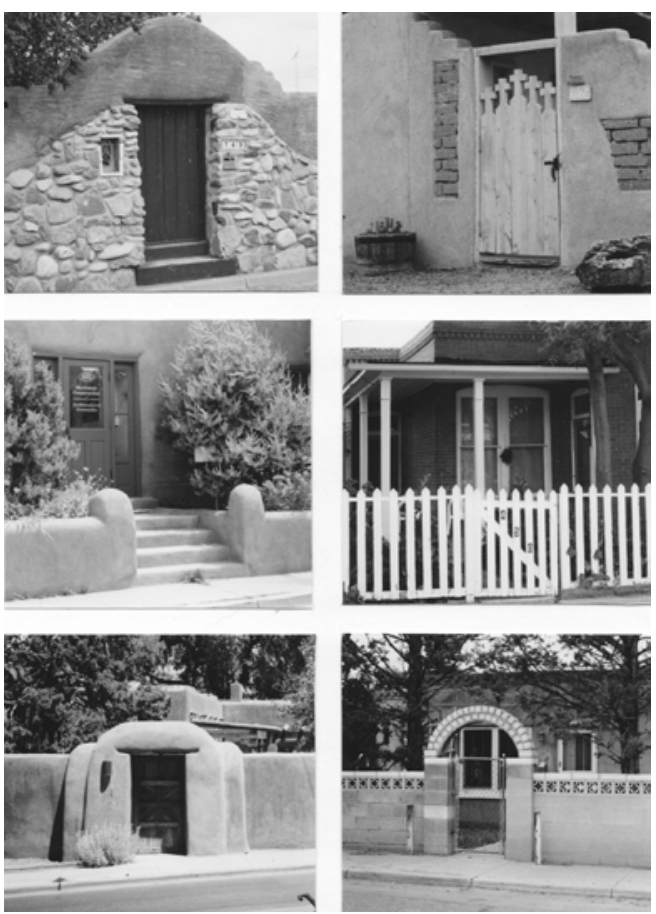

Figure 16 Various entrance schemes typical of owner- builder inventiveness.

inevitable blending of those cultures that over time fused various architectural preferences to create an extensive vocabulary of settlement patterns, building forms, and detailing.

Throughout the American Southwest modern architects blend innovation with interpretations of traditional themes. Antoine Predock's Nelson Center at Arizona State University in Tempe, Frank Ghery's Edgemar complex in Santa Monica, California, and Ricardo Legoretta's Visual Arts Center at The College of Santa Fe (see figure 18) fuse contemporary architectural themes with climatic, cultural, and material elements of Southwestern building.

Legoretta's Visual Arts Center is a relevant application of syncretistic vernacularism showing how "local and regional identities are constructed within - rather than against - the context of the modern." 16 The process of syncretism, the fusion of two or more different inflectional forms so as to form a whole, is the legacy of the Westside/Guadalupe Historic District. This process of syncretistic vernacular is widespread throughout world history particularly in countries with a history of colonialism and

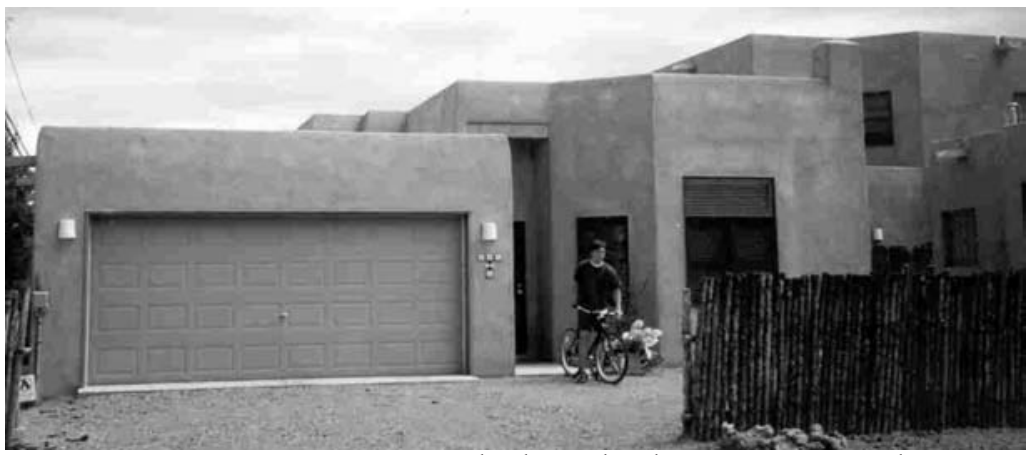

Figure 17 Contemporary Apartment Complex designed in the Recent Santa Fe Style. 


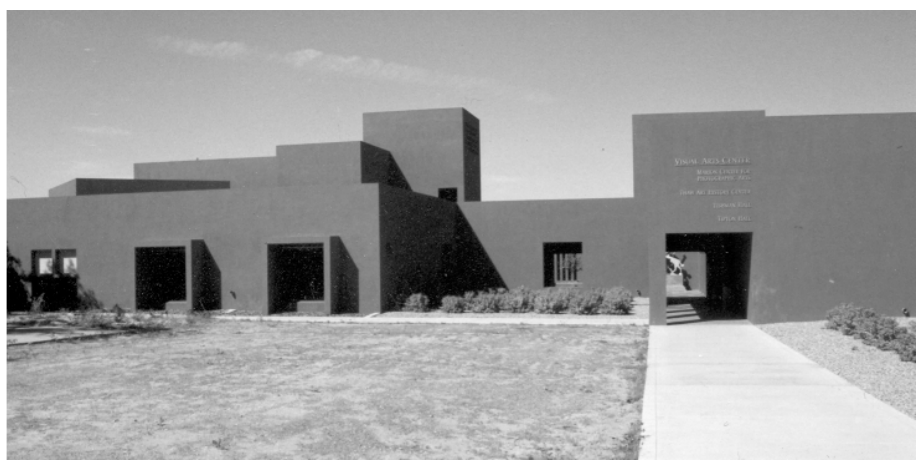

Figure 18 Visual Arts Center College of Santa Fe Ricardo Legoretta Architect

foreign invasion including Mexico, Indonesia, India, and the French Speaking Creole of Louisiana, to name just a few. The blending of architectural preferences is but one of the many ways syncretism or contextualization occurs between different cultural groups. Syncretism is often observed in cultural myths, language, and religion. "The concept of syncretism has been coined to describe the mixing of elements from different religious sources, sometimes as a descriptive term, sometimes as a pejorative concept." ${ }^{17}$ The syncretistic response to the merging of Anglo and Hispanic cultures in New Mexico during the 19th and early 20 th centuries was not a simple two-way trade. It was a conscious and deliberate action at one level and an unconscious and natural occurrence at other levels. To merely imitate history using a prescriptive approach to modern regional building based on a purely academic categorization of Spanish-Anglo vernacular expressions would repeat the excesses of the Spanish Pueblo Revival. Excesses that ultimately generated an etiological mythic in promoting what Wilson calls a "fictionalized reality", or a false history of place.

In the forward to The Place of Houses, Charles Moore claimed that "traditions have great power precisely because they present us with possibilities and guides that can support invention." ${ }^{18} \mathrm{It}$ is a community based process that challenges the ordinary efficacy of the modern consumerist driven housing product. The continued learning of, or the natural understanding of local traditions, expressed in the process and intent of the vernacular owner/builder, is evidence of a "connected" and "rooted" community capable of sustaining and perpetuating a distinctive architectural character. A neighborhood identity made authentic through the practice of locally understood cultural and technical building traditions emphasizing a dissonant and eclectic reality, the hybridization of the traditional with the modern, over a homogenous sense of oneness.

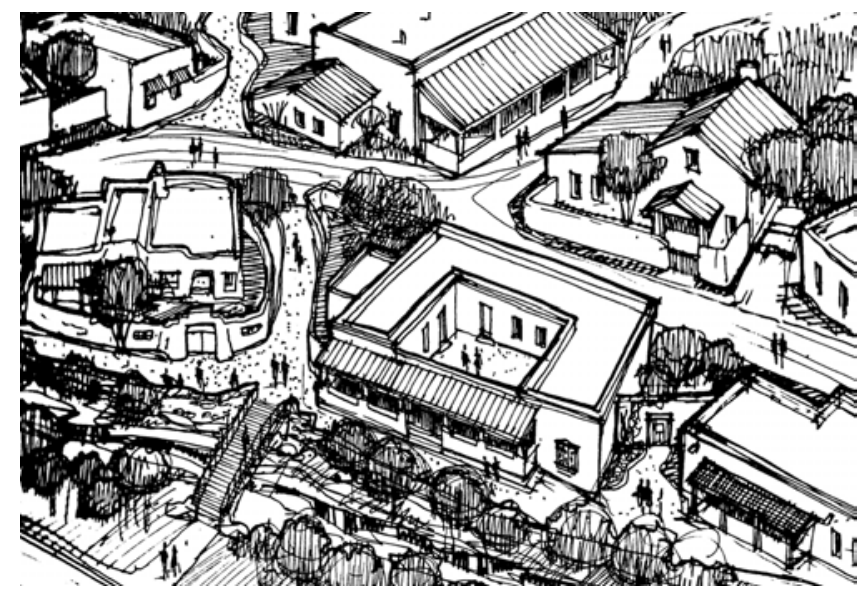

Figure 19 Aerial perspective showing detached large scale housing in courtyard and walled yard configurations. 


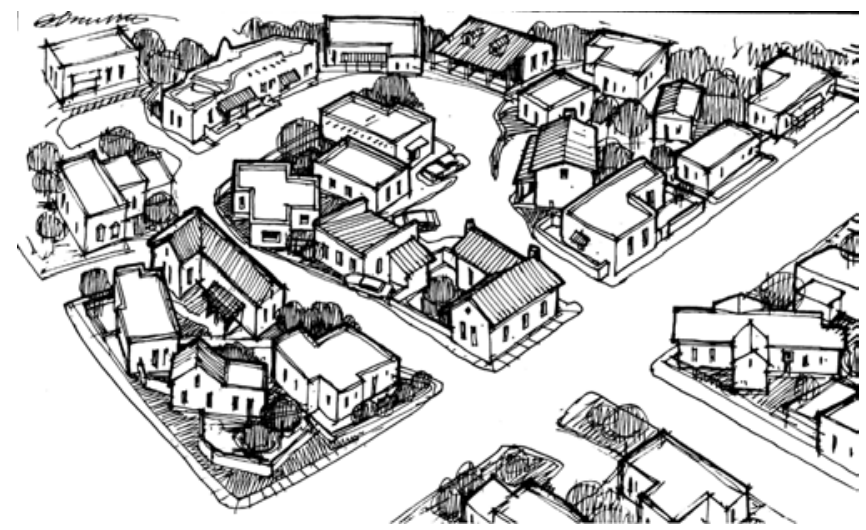

Figure 20 Aerial perspective showing organic clusters of attached and stand alone medium and small scale housing.

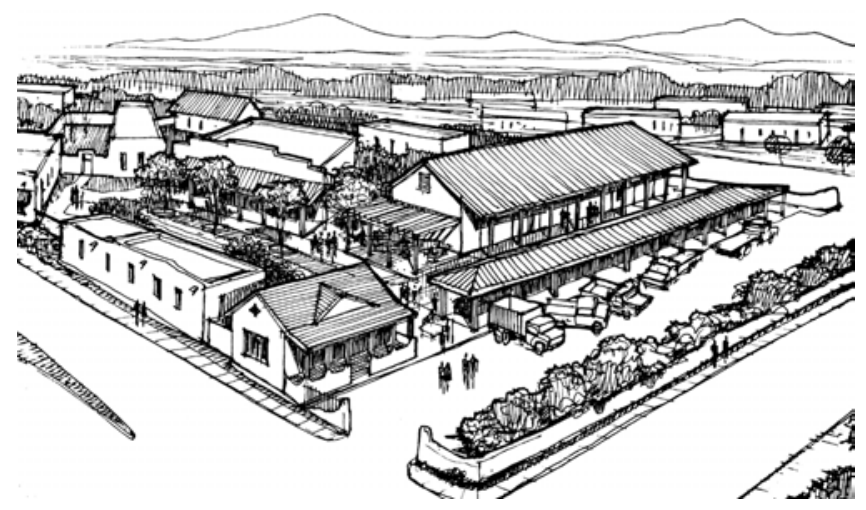

Figure 21 aerial perspectives showing conceptual mixed use development of small scale retail and multi-family housing units.

Learning from the Westside/Guadalupe Neighborhood can inspire the development of many local architectural terrains that offer more than the average suburban tract housing development. Figures 19-21 show three possible versions of new building design and community planning schemes that use traditional and modern vernacular forms and configurations to create contemporary development that denotes a specific sensitivity to place.

\begin{abstract}
A distinctive Mexican-American vernacular has continued to evolve largely unrecognized by tourists, historic-preservationist, and architectural revivalists. This owner-built vernacular continues the Spanish-Mexican tradition unbroken, with a healthy admixture of AngloAmerican influences. ${ }^{19}$
\end{abstract}

In The Vernacular, Memory, and Architecture Stanford Anderson makes a distinction between social memories or traditions in building that are embodied within preliterate societies, and disciplinary memory as practiced by professional architects in literate societies. His central thesis is that a modern vernacular architecture can be understood as the cohesion of social and disciplinary memory, and that there exists the possibility for a natural relationship between a society and its artifacts. ${ }^{20}$ Anderson's claim has particular importance for historic cultural neighborhoods like the Westside because the owner-as-builder tradition is disappearing. The continued vitality and sustainability of this place is largely up to the contractors, developers, and architects and designers that will oversee new and renovation construction, and to the next generation of home owners that will either initiate the creation of new structures, or continue the preservation of existing structures. There is no single vision for the future of the Westside that would satisfy the requirement for a simple prescriptive 
solution. "Greater homogeneity and greater heterogeneity are....simultaneously at work in the often chaotic negotiations between groups and cultures" ${ }^{21}$ This is true in the case of 20th century Santa Fe as evidenced by the eccentric folk character of the Westside contrasted against the "vernacularized" modern structures that aside from basic regional stylistic references are by all standards conventional American buildings.

A modern syncretistic Santa Fe vernacular architecture can be defined as an ongoing and evolving way of building those bridges the past with the inevitable future. It can be relevant today and in the future if it can foster the cohesion of traditional social, cultural, and ethnic preferences with modern consumerist agendas. Continue to fuse local craft with global technologies and materials. And, merge modern regulated zoning ordinances and building codes with historic traditions of ad hoc vernacular inventiveness. An inventiveness that is embodied in a commonly understood tradition that values innovation over imitation. All three of these goals require a process of building in which the community, client, designer, and contractor will require a highly developed understanding of local traditions, regional and national history, and the multifaceted and ever-changing realities of an emerging global society.

All photographs and illustrations are by the author

\section{ENDNOTES}

1. Gottfried, Herbert, Jennings, Jan, American Vernacular Buildings and Interiors (W.W. Norton and Company, Inc.,2009)intro pg. 1

2. Gottfried, Herbert, Jennings, Jan, American Vernacular Buildings and Interiors (W.W. Norton and Company, Inc., 2009) intro pg. 2 Gottfried and Jennings assert that modern vernacular buildings are constructed with manufactured building products (and not hand hewn as in preindustrial times), the plan originates from the concept of convenient arrangement, and "the production of modern vernacular buildings has a pictorial bias derived from the picturesque aesthetic."

3. The origin of the word vernacular is Latin vernaculus meaning slave, domestic, native, indigenous. The term has come to mean (1) the locally spoken dialect of a group of people of common interest or origin. (2) The building style of a particular group, locality, or climatic region.

4. Oliver, Paul, Built to Meet Needs Cultural Issues in Vernacular Architecture, (Elsevier Ltd. Architectural Press, 2006) pg. 30

5. Reeve, Agnesa Lufkin, From Hacienda to Bungalow, Northern New Mexico Houses: 1850-1912. (University of New Mexico Press, 1988) pg. 25

6. Conron, John P. and Christopher, R. Patrick, the Architecture of Santa Fe-A Survey of Styles. (City of Santa Fe,. 1980) pg. 15

7. De Buys, William, Enchantment and Exploitation, The Life and Times of a New Mexico Mountain Range, (University of New Mexico Press, 1991) pg. 101

8. Chris Wilson, The Myth of Santa Fe Creating a Modern Regional Reality, (University of New Mexico Press, 1997): pgs. 312-313

9. Gallegos, Mathew, The Arts and Crafts Movement in New Mexico 1900-1945, Master's Thesis, School of Architecture, (University of Virginia )May, 1987 pgs. 121-13

10. Gottfried, Herbert, Jennings, Jan, American Vernacular Buildings and Interiors (W.W. Norton and Company, Inc.,2009)intro pg. 9

11. Beverly Spears, AIA, Santa Fe's Westside/Guadalupe Historic District: Hispanic Vernacular Versus Pueblo Revival, (New Mexico Architecture: Sept-Dec 1990)

12. Van Dorn Hooker, Vernacular Architecture, article in New Mexico Architecture (Sept.-Dec., 1990): pg. 7

13. Syncretism Gk., syn-kretismos, "a blending", "a mixing together," "uniting") the bringing together of conflicting ideologies into a unity of thought and/or into a cooperating, harmonious relationship.(Federation of Cretan cities)

14. Kenneth Frampton, Modern Architecture A Critical History, (Thames and Hudson, 1992): pg. 3

15. James Howard Kunstler, The Geography of Nowhere The Rise and Decline of America's Man-made Landscape (Touchstone Simon and Schuster, 1993):pg. 59

16. Umbach, Maiken and Huppauf, Bernd, Vernacular Modernism Heimat, Globalization, and the Built

Environment, (Stanford University Press, 2005) intro pg. 2 
17. Daneel, Inus, Van Engen, Charles, and Vroom, Hendrik "Changing Culture and the Missiological Mission" in Fulness of Life for All. Challenges for Mission in Early 21st Century. Amsterdam: Rodopi, 2003, p.63.

18. Charles Moore, Gerald Allen, Donlyn Lyndon, The Place of Houses, (Henry Holt and Company, 1979, )into :vii

19. Wilson, Chris, Spatial Mestizaje on the Pueblo-Hispanic Frontier, article published in Mass, Journal of the School of Architecture and Planning, (University of New Mexico, Fall 1994)

20. Umbach, Maiken and Huppauf, Bernd, Vernacular Modernism Heimat, Globalization, and the Built Environment, (Stanford University Press, 2005) pg. 157-171

21. Fehrenbach, Heide, and Ute, Poiger, Transactions, Transgressions, Transformations: American Culture in Western Europe and Japan, (Berghahn Books, 2000), pg. xxxvi 